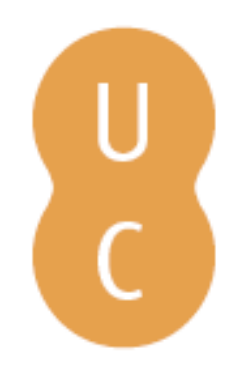

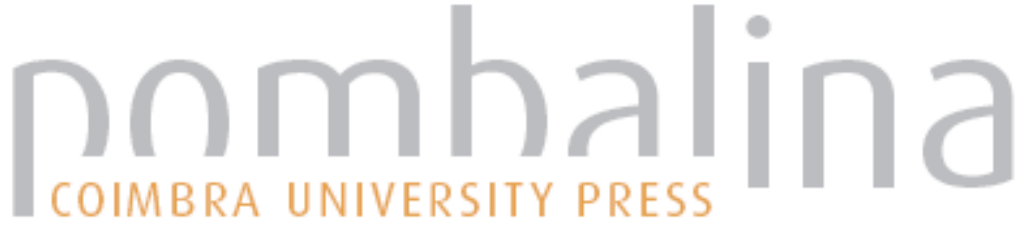

\section{Fire response to natural wind versus constant wind}

Autor(es): $\quad$ Butler, B W; Jimenez, D; Quarles, S; Obrien, J.

Publicado por: Imprensa da Universidade de Coimbra

URL

persistente: URI:http://hdl.handle.net/10316.2/44567

DOI: $\quad$ DOI:https://doi.org/10.14195/978-989-26-16-506_50

Accessed : $\quad$ 26-Apr-2023 16:15:27

A navegação consulta e descarregamento dos títulos inseridos nas Bibliotecas Digitais UC Digitalis, UC Pombalina e UC Impactum, pressupõem a aceitação plena e sem reservas dos Termos e Condições de Uso destas Bibliotecas Digitais, disponíveis em https://digitalis.uc.pt/pt-pt/termos.

Conforme exposto nos referidos Termos e Condições de Uso, o descarregamento de títulos de acesso restrito requer uma licença válida de autorização devendo o utilizador aceder ao(s) documento(s) a partir de um endereço de IP da instituição detentora da supramencionada licença.

Ao utilizador é apenas permitido o descarregamento para uso pessoal, pelo que o emprego do(s) título(s) descarregado(s) para outro fim, designadamente comercial, carece de autorização do respetivo autor ou editor da obra.

Na medida em que todas as obras da UC Digitalis se encontram protegidas pelo Código do Direito de Autor e Direitos Conexos e demais legislação aplicável, toda a cópia, parcial ou total, deste documento, nos casos em que é legalmente admitida, deverá conter ou fazer-se acompanhar por este aviso.

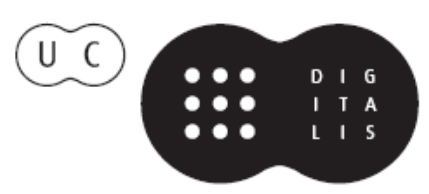




\section{ADVANCES IN}

\section{FOREST FIRE RESEARCH}

\section{8}

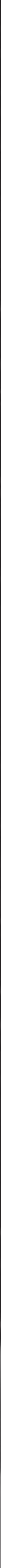




\title{
Fire response to natural wind versus constant wind
}

\author{
BW Butler ${ }^{1}$, D Jimenez ${ }^{1}$, S Quarles ${ }^{2}$; J. Obrien ${ }^{3}$ \\ ${ }^{1}$ US Forest Service, Missoula Fire Sciences Laboratory, Missoula, MT, USA, \\ \{bwbutler@fs.fed.us\} \\ ${ }^{2}$ Insurance Institute for Business and Home Safety, Rock Hill, SC USA, \\ ${ }^{3}$ US Forest Service, Southern Research Station, \{jobrien@fs.fed.us\}
}

\begin{abstract}
While the relation between wildland fire spread rate and wind has been a topic of study for over a century, very few previous studies report measurements of fire rate of spread in controlled winds exceeding $5 \mathrm{~m} / \mathrm{s}$. In this study measurements of fire rate of spread, flame residence time, and energy release are reported for fires burning under controlled atmospheric conditions in a shallow bed of pine needles subject to winds ranging from 0 to $27.2 \mathrm{~m} / \mathrm{s}(6 \mathrm{~m} \mathrm{agl})$. The data suggest that when winds are less than $5 \mathrm{~m} / \mathrm{s}$ fire rate of spread increases linearly with wind speed. As wind speed exceeds $5 \mathrm{~m} / \mathrm{s}$ the fire rate of spread response increases at a rate approximately 5 times greater. When fires are burned in winds replicating natural spatiotemporal variability in speed and direction the rate of spread is 20 to $90 \%$ greater than when burned under constant steady winds.
\end{abstract}

Keywords: fire behavior, wind

\section{Introduction}

Wind is a dominant environmental variable in wildland fire spread and intensity. The relation between wildland fire rate of spread and wind speed (aligned with the direction of fire spread) used in the US and other fire behavior decision support systems was developed from experiments in wind tunnels and open burn experiments (Fang 1969). For the most part these facilities have been limited to approximately $3 \mathrm{~m} / \mathrm{s}$ is maximum speed; however there have been some exceptions. Weise and Bigging (1996) report measurements of fire spread rate in open wind tunnel at wind speeds up to 1.1 $\mathrm{m} / \mathrm{s}$. Catchpole et al (1998) present results from a large number of experiments conducted in a closed wind tunnel with controlled air temperature and humidity at winds up to $3.3 \mathrm{~m} / \mathrm{s}$. Their work exhibits a monotonically increasing correlation between fire rate of spread and wind speed over the range of winds explored.

Others report observations from naturally burning fires. McArthur $(1966,1969)$ relates fire rate of spread in natural fuels to average wind velocity in the open for winds of $60 \mathrm{~km} / \mathrm{h}$ as observed from several fires in Australia. Winds in the natural environment fluctuate in speed and direction on relatively small temporal and spatial scales. Beer (1991) evaluates the physics underlying fire/wind interaction and proposes that the three dimensional nature of buoyant plumes above fires forms peaks and troughs that interact with local wind fields through complicated mechanisms that enhance energy transport to the unburned fuel ahead of the fire front. He posits that fluctuations in wind speed enhance the fluctuations in flame size and structure thereby enhancing advective heating of the fuels and increased spread rates. In a theoretical study Albini (1982) concludes that the only effect of wind fluctuations on fire spread rate is further fluctuations in the smoke plume above the fire. Others report a power relation between wind and fire spread rate with the wind raised to an exponent of 1.5 (Nelson and Adkins 1987; Nelson Jr and Adkins 1988). Beer (1993) examines data for winds up to $9.2 \mathrm{~m} / \mathrm{s}$ and posits a power-law relation with two regimes (winds less than $2.5 \mathrm{~m} / \mathrm{s}$ and winds greater than $2.5 \mathrm{~m} / \mathrm{s}$ ) he proposes that the relative contribution of radiant and convective energy to the fire spread depends on wind speed, with increased convective heating for increased winds (Beer 1991). 
In this study the rate of spread and intensity of fires burning over a bed of pine needles for a wind speeds from 0.4 to $27 \mathrm{~m} / \mathrm{s}$ are measured. The winds speeds cover a much higher range than has been reported previously for any laboratory based study. To our knowledge no laboratory-based studies exist that explore the relation between fire rate of spread and a "natural" wind history under laboratory controlled conditions.

\section{Methods}

Here we report the results of twelve experiments completed at The Insurance Institute for Building and Home Safety (IBHS) located in Richburg, SC. This facility includes a large wind tunnel (approximate footprint of experimental floor space 35 by $50 \mathrm{~m}$ ) that has the capability to generate three wind conditions: 1) a constant wind speed (fan speeds held constant to generate a wind speed specified with the representative typical logarithmic boundary layer profile and 2) a nominally "semi-natural" wind history with fluctuations in the longitudinal wind direction and 3) a fully "natural" wind field with fluctuations in both the longitudinal and lateral components. Here we compare results from seven fires conducted under wind condition 1, one fire burned under wind condition 2 and five fires burned under wind condition 3 . The facility has the capability to generate winds between 5 and $63 \mathrm{~m} / \mathrm{s}$ (see Figure 1 left). Longitudinal speed is controlled by modulating fan rotational speed at the plenum inlet to replicate a wind speed record collected from a sensor in an open field. Wind direction is controlled by modulating vanes at the exit of each plenum to redirect the wind speed over a nominal range of \pm 20 degrees, replicating a directional wind record measured in an open field. Through these two features the wind field in the test chamber can be controlled to exactly replicate a wind field measured in the natural environment.

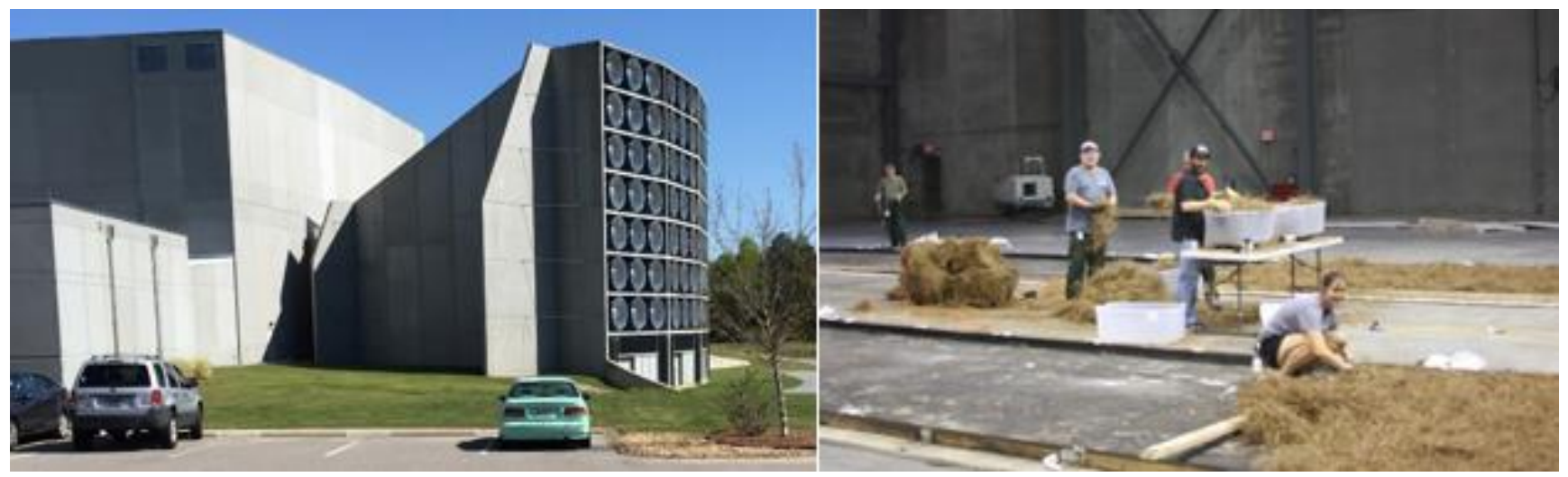

Figure 1 - Exterior photo of IBHS facility with fans (left image) and experimental chamber (right image) where staff are constructing fuel beds in preparation for a burn.

For this study two parallel fuel trays nominally $3 \mathrm{~m}$ wide by $24 \mathrm{~m}$ long were constructed on the floor of the IBHS facility (Figure 1 right). Fuel trays were equally spaced laterally along the longitudinal axis of the wind flow. The bed width was selected to minimize the effect of fire front width on rate of spread (Wotton et al. 2000a, 2000b). The fuel trays consisted of a double layer of 1.58 $\mathrm{cm}$ thick $244 \mathrm{~cm}$ long by $122 \mathrm{~cm}$ wide gypsum boards (total thickness $3.16 \mathrm{~cm}$ ) placed on the floor of the tunnel. The fuel tray sides were $8.9 \mathrm{~cm}$ tall. The lateral edges of the trays were separated by approximately $3 \mathrm{~m}$. Burn number, wind speed, fuel moisture, average rate of spread, and residence time are presented in table 1. 
Table 1 - Experimental conditions and key measurements averaged over both beds

\begin{tabular}{|c|c|c|c|c|c|c|}
\hline $\begin{array}{c}\text { Burn } \\
\#\end{array}$ & $\begin{array}{c}\text { Wind } 5 \mathrm{~m} \\
\text { above floor at } \\
\text { exit of } \\
\text { plenum }(\mathrm{m} / \mathrm{s})^{3}\end{array}$ & $\begin{array}{l}\text { Ave wind at } \\
\text { fuel surface } \\
\qquad(\mathrm{m} / \mathrm{s})^{1,3}\end{array}$ & $\begin{array}{l}\text { Flow } \\
\text { type }\end{array}$ & $\begin{array}{c}\text { Average fuel } \\
\text { moisture content } \\
(\% \text { dry mass })^{3}\end{array}$ & $\begin{array}{c}\text { Fire ROS } \\
\text { for both } \\
\text { beds } \\
(\mathrm{m} / \mathrm{s})^{3} \\
\end{array}$ & $\begin{array}{c}\text { Average } \\
\text { residence time } \\
(\mathbf{s})^{3}\end{array}$ \\
\hline 4 & $14.7(1.3)$ & $10.5(0.25)$ & $\mathrm{C}$ & $6.5(1.2)$ & $0.80(0.11)$ & $24.7(4.4)$ \\
\hline 5 & $14.7(1.3)$ & $10.7(1.4)$ & RW & $5.1(1.1)$ & $1.02(0.07)$ & $25.7(3.7)$ \\
\hline 6 & $14.3(1.0)$ & $10.2(0.44)$ & $\mathrm{C}$ & $7.8(2.4)$ & $0.64(0.08)$ & $30.2(3.0)$ \\
\hline 7 & $14.1(1.0)$ & $10.1(0.34)$ & $\mathrm{C}$ & $5.2(0.3)$ & $0.66(0.07)$ & $26.5(4.2)$ \\
\hline 8 & $10.8(2.2)$ & $8.24(0.88)$ & $\mathrm{R}$ & $4.2(0.8)$ & $0.84(0.06)$ & $24.0(2.4)$ \\
\hline 9 & $12.0(1.1)$ & $9.0(0.34)$ & $\mathrm{C}$ & $6.9(0.5)$ & $0.57(0.06)$ & $27.0(5.3)$ \\
\hline 10 & $11.7(1.2)$ & $8.8(0.51)$ & $\mathrm{C}$ & $7.5(2.7)$ & $0.67(0.084)$ & $23.0(2.6)$ \\
\hline 11 & $11.9(2.5)$ & $9.2(0.89)$ & $\mathrm{R}$ & $6.2(0.6)$ & $0.83(0.04)$ & $25.8(3.2)$ \\
\hline 13 & $8.7(1.4)$ & $7.4(0.81)$ & $\mathrm{R}$ & $8.7(0.3)$ & $0.32(0.05)$ & $25.8(4.6)$ \\
\hline 14 & $10.4(0.9)$ & $7.7(0.33)$ & $\mathrm{C}$ & $8.5(1.8)$ & $0.34(0.05)$ & $25.2(2.7)$ \\
\hline 15 & $15.3(3.3)$ & $12.3(0.97)$ & $\mathrm{R}$ & $7.4(2.6)$ & $0.91(0.13)$ & $19.7(5.2)$ \\
\hline 16 & $20.8(1.6)$ & $15.3(0.34)$ & $\mathrm{C}$ & $7.2(0.3)$ & $1.69(0.13)$ & $20.3(2.4)$ \\
\hline
\end{tabular}

${ }^{1}$ sensor located $28 \mathrm{~cm}$ above fuel tray surface $(20.4 \mathrm{~cm}$ above upper surface of fuel) at location $20 \mathrm{~m}$ along length of bed.

${ }^{2} C$-constant wind speed and direction, $R$ - "natural wind" with speed and direction varying in time, $R W$-speed varying in time but direction held constant.

3 average followed by standard deviation in parentheses.

A common landscaping material in this region of the United States consists of bales dead pine needles (primarily from Slash (Pinus elliottii) and long leaf (Pinus palustris) pine trees), this material is commonly referred to as pine straw. Taking advantage of the availability of this material, a supply of pine straw bales was purchased and stored in a climate controlled container. Immediately prior to each burn sufficient amounts of bales were removed from storage, separated into weighed amounts and distributed on the fuel trays to a target fuel depth $(8.9 \mathrm{~cm})$ and bulk density (packing ratio) per unit area of 0.02 . Fuel loading was nominally $0.84 \mathrm{~kg} / \mathrm{m}^{2}$ adjusted for moisture content. Samples of fuels were collected immediately prior to ignition from nominally $3 \mathrm{~m}$ and $20 \mathrm{~m}$ along the longitudinal axis of each fuel bed to determine fuel moisture content. Moisture content was nominally $15 \%$ for burns 1 and 2,12\% for burn 3, and between 5 and $8 \%$ for all other burns.

In a typical burn, pine needles were distributed at specified depth and bulk density, data loggers were started, fuel moisture samples were collected, wind fans were set to the idle setting $(\sim 5 \mathrm{~m} / \mathrm{s})$. Once all preparations were complete the leading edge of the fuel beds was ignited manually using handheld propane torches, as soon as the flame front was established personnel left the area. At this time the fans would be sped up to the target wind speed and profile. Time between ignition and fan ramp up was less than 3 seconds. Time for fans to accelerate from idle to full speed was less than 3 seconds. After a burn was complete the ash residue was removed and a new fuel bed constructed. 


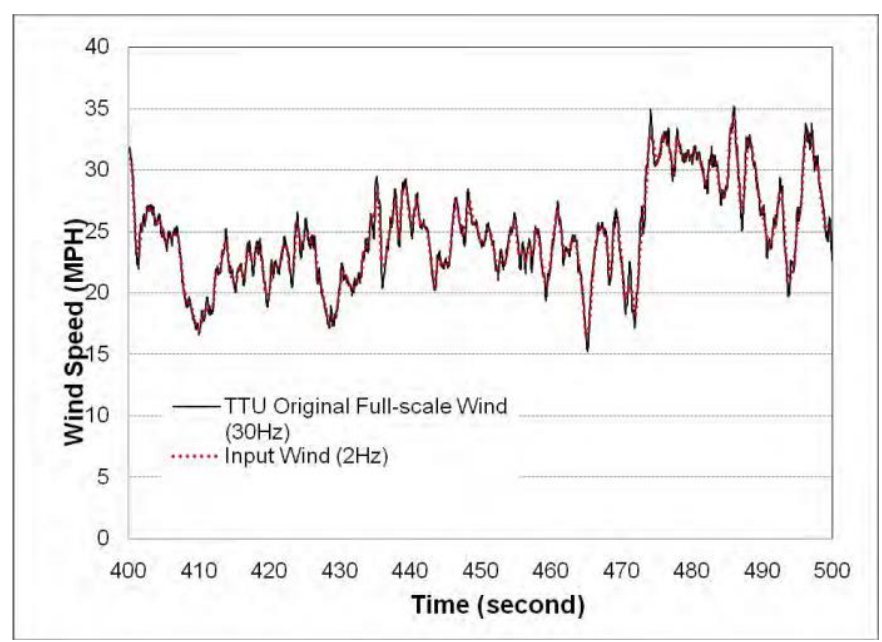

Figure 2 - Wind speed as measured in open terrain and replicated by the IBHS facility. Source http://disastersafety.org/wp-content/uploads/2015/07/wind-flow-validation-report_IBHS.pdf

Fire rate of spread was characterized from analysis of overhead visual video records. For this method visible targets were placed on the rail forming the edge of the fuel tray and on the floor between the two fuel beds. These targets had a length designation as well as a unique identifier that was visible in the video image (a number constructed of aluminum foil). Overall rate of spread was calculated by recording the fire front transit time between 5 and $24 \mathrm{~m}, 10$ and $20 \mathrm{~m}$, and 15 and $24 \mathrm{~m}$ along the bed tray length except for the zero wind burn where rate of spread was calculated as the time to spread from 0 to 3,1 to 2 and 2 to $3 \mathrm{~m}$.

Flame residence was calculated from overhead video record as the time for the flame front to spread over a specified distance. Ending time was defined as that which the majority of flaming combustion was complete; as for many cases at the higher wind speeds the partially burned fuel bed was blown down the fuel tray, essentially forming a secondary flaming and smoldering rolling flame front.

For a subset of experiments, radiant and convective heating were measured by sensors located approximately $0.5 \mathrm{~m}$ high at 5 and $25 \mathrm{~m}$ along the longitudinal axis of the fuel tray. These sensors have been described elsewhere (Butler et al. 2010; Frankman et al. 2013a) and are designed to measure heating from the flame incident on the sensor as the flames approach and burn around the sensor. Sensors were sampled at $10 \mathrm{hz}$. Reported values represent $3 \mathrm{~s}$ averages of the measured signal (Frankman et al. 2013b).

\section{Results and Discussion}

The experiments were performed with winds varying in both speed and direction. The relevant data are grouped by target wind speed $6.8,7.9,9,11.3 \mathrm{~m} / \mathrm{s}(15,17.5,20$ and $25 \mathrm{mph})$ and are shown in figure 3. In all cases the average rates of spread for the natural wind field driven fires were 20 to $90 \%$ greater than the fires burning under the constant speed wind over the range of average wind speeds of 9 to $15 \mathrm{~m} / \mathrm{s}$.

The time averaged wind speeds within a specific target wind speed group varied slightly between experiments, for example two separate burns of two beds each were conducted for the 20-C group with a slightly different average speed between burns. This variation is due to slight differences in the burning environment such as winds around the exterior of the facility and relative humidity; but in all cases the average rate of spread for the "natural" wind driven fires was faster than that for the constant speed wind driven fires across all target wind speed groups even when the average speed for the "natural" wind was slightly lower than that of the constant wind burns (i.e. 15-C and 15-R data). Of particular interest is the single burn set that was conducted at a target of $11.3 \mathrm{~m} / \mathrm{s}(25 \mathrm{mph})$ with 
constant speed but varying direction (data set 25-C-R). The rate of spread for these fires was greater than the constant wind case and similar to the fully "natural" wind case. While this is just one data point it implies that the higher fire spread rates associated with the natural winds are not due to the pulses in wind speed that exceed the average speed, but are rather due to turbulence introduced by the directional variations. This observation has implications to modeling of fire spread and warrants further exploration. The range of wind speeds explored in this study was not sufficient to explore the presence of the two regimes for natural winds as was observed for the larger data set.

While not shown here, measurements of radiant and total energy release were collected for a subset of the experiments. Radiant energy release was nominally two to ten times greater than the convective heating for the constant speed wind driven fires and five to ten times greater than the convective heating for the "natural" wind driven fires suggesting that turbulence and convective heating events are more common in fires burning under "natural" winds.

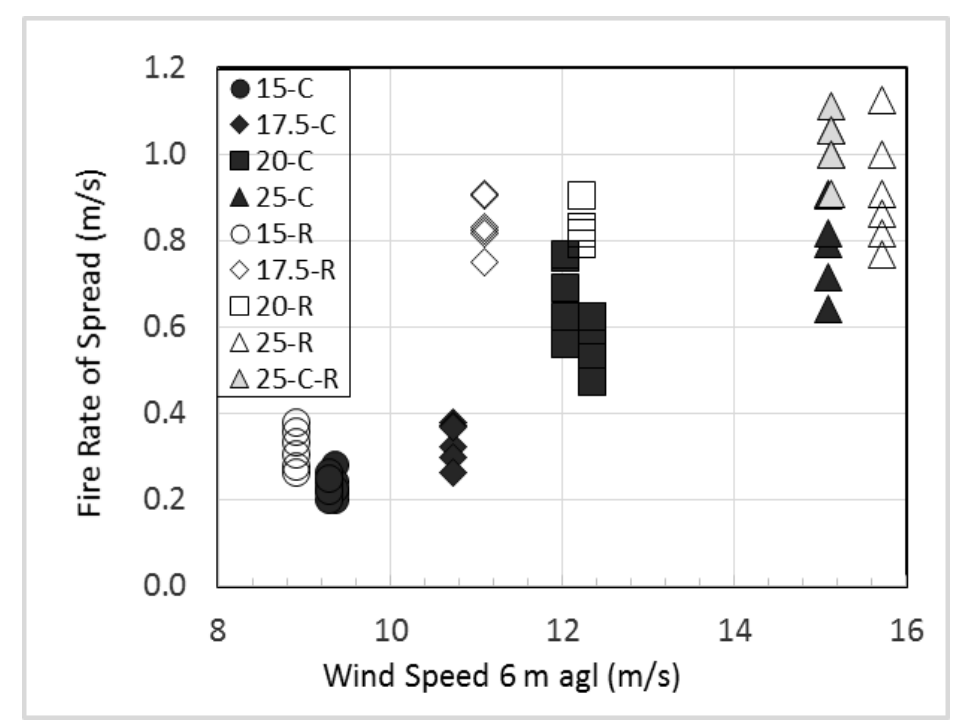

Figure 3 - Fire rate of spread under constant and naturally varying wind fields. The data are arranged by target average wind speed and wind type (e.g. 15-R indicates $15 \mathrm{mph}(6.8 \mathrm{~m} / \mathrm{s})$ target speed at "real" wind conditions, 20-C represents target average wind speed of $20 \mathrm{mph}(9 \mathrm{~m} / \mathrm{s})$ at constant speed and direction, 25-C-R represents a constant fan speed and varying direction wind condition).

\section{Conclusions}

This work explores the relation between wind speed and fire spread rate in fine dead fuels for a wider range of winds speeds than any previously reported efforts. The effort includes a limited exploration of the response of fire to natural winds (that is winds that vary in speed and direction). The results suggest that natural winds result in faster fire spread rates than a constant wind at the same average speed. This finding has significant implications to the development of models simulating fire growth. In the context of the wind limit observed in the MacArthur (1969) data and imposed by Rothermel (1972) in his original model, an optimum wind speed can be postulated based on the expectation that at some high wind flow convective cooling will dominate any heating thus the flame will essentially be "blown" out. As concluded by others (Andrews et al. 2013) these data did not exhibit a wind limit, at least up to a wind speed of $27 \mathrm{~m} / \mathrm{s}(60 \mathrm{mph})$. However, the data do show a nonlinear relation between wind speed and fire rate of spread. The increased dependency as wind exceeds $6 \mathrm{~m} / \mathrm{s}$ and the indication that fires spread faster under natural winds than constant winds has implications to both fire behavior and fire danger rating systems.

Advances in Forest Fire Research 2018 - Page 470 


\section{Acknowledgements}

This work was supported through funding provided from the office of the US Forest Service Deputy Chief for Research. The gracious assistance of the IBHS staff during the experiments is also appreciated as are the comments from the anonymous reviewers.

\section{References}

Albini, FA (1982) Response of free-burning fires to nonsteady wind. Combustion Science \& Technology 29, 225-241.

Andrews, PL, Cruz, MG, Rothermel, RC (2013) Examination of the wind speed limit function in the Rothermel surface fire spread model. International Journal of Wildland Fire 22, 959-969.

Beer, T (1991) The interaction of wind and fire. Boundary-Layer Meteorology 54, 287-308.

Beer, T (1993) The speed of a fire front and its dependence on wind speed. International Journal of Wildland Fire 3, 193-202.

Butler, BW, D Jimenez, J Forthofer, K Shannon, and P Sopoko. (2010) A Portable System for Characterizing Wildland Fire Behavior. Paper presented at the Proceedings of the 6th International Conference on Forest Fire Research.[CD-ROM]. Coimbra, Portugal: University of Coimbra.

Catchpole, WR, Catchpole, EA, Butler, BW, Rothermel, RC, Morris, GA, Latham, DJ (1998) Rate of spread of free-burning fires in woody fuels in a wind tunnel. Combustion Science Technology 131, $1-37$.

Fang, JB (1969) An investigation of the effect of controlled wind on the rate of fire spread. University of New Brunswick.

Frankman, D, Webb, BW, Butler, BW, Jimenez, D, Forthofer, JM, Sopko, P, Shannon, KS, Hiers, JK, Ottmar, RD (2013a) Measurements of convective and radiative heating in wildland fires. International Journal of Wildland Fire 22, 157-167.

Frankman, D, Webb, BW, Butler, BW, Jimenez, D, Harrington, M (2013b) The effect of sampling rate on interpretation of the temporal characteristics of radiative and convective heating in wildland flames. International Journal of Wildland Fire 22, 168-173.

McArthur, AG (1966) Weather and grassland fire behaviour. Commonwealth of Australia No. No. 100, Canberra, Australia.

McArthur, AG (1969) The Tasmanian bushfires of 7 February 1967 and associated fire characteristics. In 'Mass Fire Symposium. Canberra ACT Australia'. (Defence Standards Laboratories, Maribymong, Victoria:

Nelson Jr, RM, Adkins, CW (1988) A dimensionless correlation for the spread of wind-driven fires. Canadian Journal of Forest Research 18, 391-397.

Nelson, RM, Jr, Adkins, CW (1987) A dimensionless correlation for the spread of wind-driven fires.

Rothermel, RC (1972) A mathematical model for predicting fire spread in wildland fuels. No. USDA Forest Service Research Paper INT-115, Ogden, UT.

Weise, DR, Biging, GS (1996) Effects of wind velocity and slope on flame properties. Canadian Journal of Forest Research 26, 1849-1858.

Wotton, B, McAlpine, R, Hobbs, M (2000a) The effect of fire front width on surface fire behaviour. International Journal of Wildland Fire 9, 247-253.

Wotton, BM, McAlpine, RS, Hobbs, MW (2000b) The Effect of Fire Front Width on Surface Fire Behavior. International Journal of Wildland Fire 9, 247-253. 